\title{
Estimation of Organic Soils Subsidence in the Vicinity of Hydraulic Structures - Case Study of a Subirrigation System in Central Poland
}

\author{
Andrzej Brandyk ${ }^{* *}$, Ryszard Oleszczuk ${ }^{2}$, Janusz Urbański ${ }^{3}$ \\ 1 Water Centre, Warsaw University of Life Sciences, ul. Ciszewskiego 6, 02-766 Warsaw, Poland \\ 2 Institute of Environmental Engineering, Warsaw University of Life Sciences, ul. Nowoursynowska 159, \\ 02-787 Warsaw, Poland \\ ${ }^{3}$ Institute of Civil Engineering, Warsaw University of Life Sciences, ul. Nowoursynowska159, 02-787 Warsaw, \\ Poland \\ *Corresponding author's e-mail: andrzej_brandyk@sggw.edu.pl
}

\begin{abstract}
The consequences of organic soil subsidence gained considerable importance in a wide range of scientific literature. Since most of the works focused mainly on the subsidence of the land surface, less attention was paid to the effects on hydraulic structures, either to their malfunctioning or to the proper management of the subirrigation systems. For the reasons mentioned above, the paper considers the selected technical parameters (underground pipelines covering thickness and soil subsidence behind inlet and outlet protections) of 37 culverts (communication structures) and 42 culvert-gates (communication and water damming). All the structures were located within the area of a subirrigation system on the previously drained organic soils (Solec system, Mazovian Voivodship, $30 \mathrm{~km}$ south of Warsaw). They underwent field measurements of the pipelines covering subsidence and land surface lowering behind their protections on the left and right side of the inlet and outlet section. The achieved results were confronted with the adopted limit and admissible values. Due to the progressing congestion and subsidence of organic soil, the covering thickness of pipelines did not exceed the limit value for $38.5 \%$ of the culverts and $36 \%$ of culvert-gates. From a long-term perspective (1971-2014) the average subsidence rates in the vicinity of the structures and surrounding peatland surface were found as comparable, ranging from 0.63 to $0.83 \mathrm{~cm} /$ year. Particular attention was paid to the influence of water damming that was evident for the inlet sections of culvertgates showing considerably lower subsidence and damage degree.
\end{abstract}

Keywords: organic soils, subsidence, sub-irrigation system, hydraulic structures, technical parameters, culverts and culvert-gates.

\section{INTRODUCTION}

The decrease of the organic soils moisture content through the ground water table decline for the purposes of the multifunctional use (e.g. agriculture, forestry or horticulture) launches a number of negative occurrences, contrary to mineral soils. They involve, first of all, physical processes, such as: congestion, consolidation and shrinkage [Hendriks 2004; Oleszczuk 2011; Gebhard et al. 2012; Ilnicki et al. 2016]. Furthermore, they impose the premises for the development of chemical processes, including moorshing and mineralization that contribute to the greenhouse gases emission in particular [Berglund et al. 2010; Couwenberg 2011; Deverel et al. 2016; Lipka et al. 2017].

Contemporary records show that $15-20 \%$ of peatlands were used for agriculture worldwide with various intensity e.g. to about $85 \%$ in the Netherlands and Germany but in Finland - only to $2 \%$ [Oleszczuk et al. 2008]. Their areas were subject to the drainage-irrigation practices for the sake of effective water management. One of the goals was to preserve the meadow-type use with the recommended ground water table 
depth between $0.3-0.8 \mathrm{~m}$, while for the arable lands, the required range was from 1.0 to $1.2 \mathrm{~m}$ [Joosten et al. 2002]. However, the drainage of peatlands had consequences such as subsidence and finally disappearance in the longer time span, which was the aftermath of two basic processes: a physical one (buoyancy decline, shrinkage and organic matter congestion) and a chemical one (organic matter decomposition due to the increased atmospheric air accessibility). The rate of subsidence and the disappearance of peatlands was said to depend mainly on the drainage depth and groundwater drawdown time, climatic conditions, peat soil type, land use form and the aforementioned water management in subirrigation systems. The thickness of organic soils as well as the occupied area decreased, which frequently leads to their complete disappearance from natural environment [Berglund et al. 2010; Hoogland et al. 2012; Grzywna 2017]. On the other hand, the impact of the above-mentioned processes on the physical status of drainage-irrigation systems on those areas was manifested through the subsidence of ditch and suppliers' banks (line-type structures) and transformations of natural water courses, mainly their shallowing. All those occurrences together create the need of proper insight into the future fate and technical prosperity of those systems [Chrzanowski et al. 2002; Oleszczuk et al. 2017; Urbański et al. 2018]. If point structures are taken into consideration, i.e. communication ones (culverts) and water damming (culvert-gates), the decrease of drained organic soil thickness takes effect in the reduction of underground pipes (culvert pipes) covering. In extreme cases, the underground parts of the structures may be visibly exposed to the atmospheric conditions or subject to different failures, mechanical damage and unsealing as well as limited accessibility of the renovation and maintenance works. Excessive soil subsidence in the surroundings of those structures can affect their stability, which is visible through cracks and crushing of the inlet and outlet sections of the underground pipes. As a result, water damming in the drainage-irrigation system begins to encounter difficulties. Moreover, high acidity of organic soils should not be overlooked, because in aquatic environment it may have a negative influence on the condition of the metal and concrete parts of the structures [Bednarczyk et al. 2009; Mioduszewski et al. 2009].
The majority of contemporary research on the drained soils subsidence focused on the range and intensity of that process with the emphasis mainly on the soil surface. Considerably smaller interest was paid to the effects of the subsidence on the functioning of the subirrigation systems within the drained peatlands, in particular on the physical condition of hydraulic structures due to terrain lowering in their vicinity. In contemporary times, the observed climatic changes, as well as prolonged hydrological and soil droughts, cause the previously drained peat soils to become increasingly sensitive to further desiccation and degradation followed by disappearance from the natural environment [Zając et al. 2018]. Because of those facts, it has been ascertained for many years that their hydrological regime and soil water conditions should be restored to a more natural state [Grand-Clement et al. 2013; Wallage et al. 2006]. The first suggested measure is to block the water outflow from drainage ditches and implement water damming by the existing point structures (culvert-gates, gates and weirs). After the evaluation of their physical condition, the necessary range of repairs and renovation becomes feasible and enables further installation of elements for water level rising. In order to make it operational on the drained peatland areas, it is recommended to evaluate the status of those structures and then the range of subsidence of organic soils at their base level as well as in the vicinity of the structures. Then, it becomes indispensable to make comparisons with peatland surface subsidence over the whole object.

Having considered the persistence of the above-mentioned occurrences the aim of this paper was the quantification of the actual condition of the selected elements of the structures: the thickness of underground pipes covering, but also the base level of bank and bottom protections against the surrounding terrain elevation. It was focused on two types of the structures: culverts (communication structures) and culvert-gates (used for water damming) for a selected case study of a subirrigation system. Moreover, the analyses were supported by the estimation of long-term organic soil subsidence directly at the structures through comparisons between the measurements performed at the moment of their construction (1971) and those conducted in 2014. 


\section{STUDY SITE AND RESEARCH METHODOLOGY}

In Poland, about $80 \%$ of fen peatlands were drained in 1960s and 1970s for agricultural needs, which cover approximately 820 thousand hectares. According to Czaplak and Dembek (2000) only $21 \%$ of that area were equipped with hydraulic structures for water damming, however, due to their poor technical condition, different organization constraints as well as the sociological and economic issues (gradual withdrawal of agriculture from those lands), the structures have been scarcely used for irrigation [Ilnicki et al. 2016].

For the detailed analyses herein, a typical subirrigation object in Central Poland was selected, representative for the intensity of organic soils drainage on the country scale. The analyzed area is located close to the Solec village, in the central part of the Mała river basin, which is the left-side tributary to Jeziorka river. In administrative respect, the area is situated within the Mazovian voivodship, the Góra Kalwaria commune (Piaseczyński province) about $30 \mathrm{~km}$ south of the capital city of Warsaw (Figure 1). Its total surface of about 290 ha is characterized by relatively small width (about $0.7 \mathrm{~km}$ ) but considerably higher length (approximately $3.2 \mathrm{~km}$ ). Most of the area is covered by organic soils of a high decomposition degree of the top layers, amounting to $90 \%$ of the area, while the remaining part involves mineral soils. The peat thickness is equal to $0.3 \mathrm{~m}$ at the object peripheries, close to the supplier A, and about $1.2 \mathrm{~m}$ in the central part along the Mała river. It is underlain by highly permeable sandy deposits [Oleszczuk et al. 2014].

First land reclamation works in the analyzed area took place between 1941-1943. Then, the period 1968-71 involved system renovation and the construction of a drainage-irrigation ditch network along with 37 communication structures (culverts), 42 culvert-gates (water damming ones) and 3 weirs (Figure 2). The underground pipelines of the culverts and culvert-gates were made of concrete pipes of a $0.6 \mathrm{~m}$ diameter and $6.0 \mathrm{~m}$ in length. They were covered by organic soil layer (peat layer) of a thickness equal to $0.6 \mathrm{~m}$. The inlet and outlet sections of the structures were arranged as protections (of banks and the bottom) in the form of concrete walls with the thickness of $0.3 \mathrm{~m}$ and the width adjusted to ditch cross-sectional dimensions. The execution of drainage-irrigation practices on the research area ceased 20 years ago, and at present only the local water board conducts seasonal (every 3 to 4 years) conservation (mowing and desludging) of the Mała river reach and supplier A.

From the viewpoint of the consequences of the subsidence-related processes, the evaluation of the physical condition of all the above-mentioned structures was performed from April to September of 2014 adopting the methodology by Kaca and Interewicz [1991]. That methodology facilitates the quantification of the technical condition of a device, a group of devices or the whole object either system. Its basis was achieved through a range of analyses of the existing subirrigation systems, and also monitoring of hydraulic structures as well as secondary devices (ditches and drains), published in the form of the design principles [Oleszczuk et al. 2014; 2017]. The method provided the admissible and limit values of the parameters for the estimation of pipe culverts and water damming structures physical status, given in Table 1.

The thickness of the pipelines covering by organic soil was measured with the use of soil auger in three spots: at inlet, in the middle and the

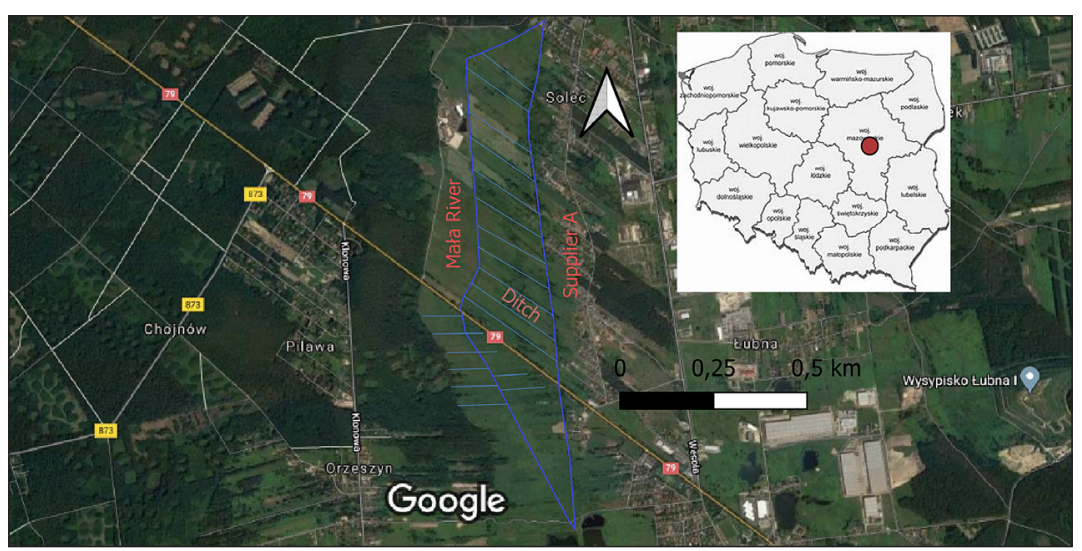

Fig. 1. Location of the Solec object 


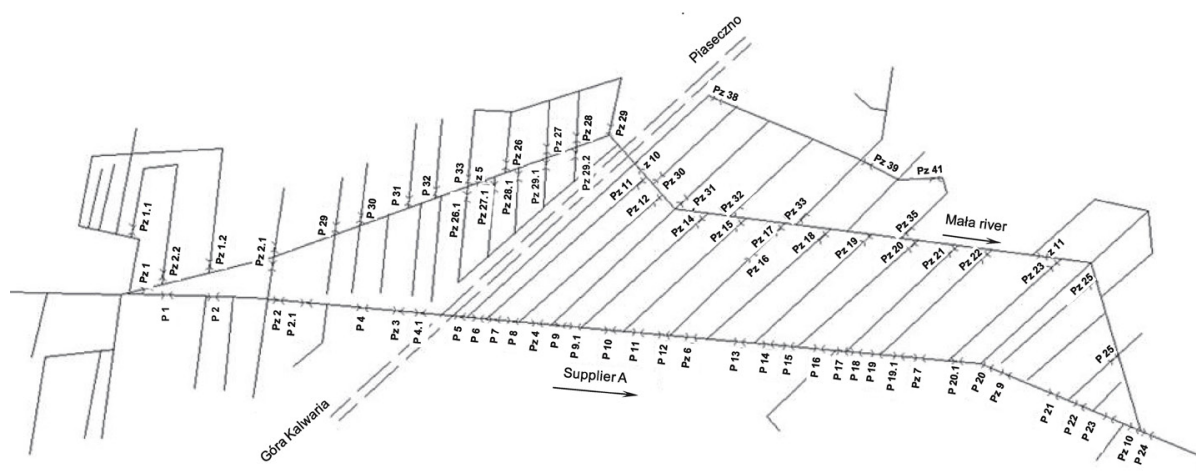

Fig. 2. Scheme of the subirrigation system

outlet. The elevations of the protections in reference to the ground level were examined at the inlet and the outlet of the culverts and culvert-gates at their left and right side with the use of geodetic patch (Figure 3).

\section{RESULTS}

\section{Physical status of the structures}

It was found that the majority of the culverts, located within the research area, were not covered by the required soil thickness, equal to $0.6 \mathrm{~m}$. Except for the culvert $\mathrm{p} 16$, none of them reached the admissible value $(50 \mathrm{~cm})$, and the following culverts: p9, p10, p12, p14, p18, p19, p19.1, p33 (Figure 4a) did not exceed the limit value $(30 \mathrm{~cm})$ at their whole length $(6.0 \mathrm{~m})$. Other pipelines were characterized by considerably smaller covering thickness (below $30 \mathrm{~cm}$ ). Secondly, the case of the culvert-gate pipelines revealed that only one, i.e. pz28.2, was covered by proper soil thickness of $60 \mathrm{~cm}$ (admissible value) at its whole length. The existing covering of the pipelines of the following culvert-gates: pz4, pz9, pz1.2, pz26.1, pz27.1, pz27, pz31, pz14, pz15, pz16, pz17 and pz20 did not exceed the limit value (that is $30 \mathrm{~cm}$ or more). Particular attention was paid to the structure pz33, the pipeline of which was subject to the exposure of about $20 \mathrm{~cm}$ above ground, as an effect of surrounding terrain subsidence
(Figure 4b). The lowest thickness of the covering of pipeline elements (inlet, the middle part, and the outlet) of the culverts was found in the final reach of supplier A (Figure 4a), while for the culvert-gates, a similar case was evident for the middle reach of the Mała River (Figure 4b).

Figure 5 illustrates the measured exposure height values of the culvert protections (negative values) and possible covering (positive values). The soil surface elevation in the vicinity of the protections on their left and right side seems similar at the inlet as well as the outlet part (Figure 5a,b). It was noted for the culverts: $\mathrm{p} 5, \mathrm{p} 6, \mathrm{p} 7, \mathrm{p} 8, \mathrm{p} 9$ and $\mathrm{p} 10$ that the soil surface level in their surroundings was equal to their upper edge ( 0 value on the graph) which stands for the preservation of the designed subsidence range in reference to the terrain altitude. This is due to the fact that part of the subirrigation system (located along supplier A), which contains the culverts, is underlain by mineral-organic soils of inconsiderable subsidence. However, for a couple of the analyzed protections, both at the inlet and the outlet, the ground level overtops their upper edge (positive values in Figure 5). This suggests the overgrowing of their elements with turf since they have been surrounded by the lands used as meadows. On the other hand, the culverts located along the Mała river showed considerable damage of the protections, most likely due to their exposure after a progressing subsidence of the organic soils found at that location (Figure 5). The

Table 1. Technical parameters for the estimation of pipe culverts and water damming structures status [Kaca and Interewicz 1991]

\begin{tabular}{|l|c|c|}
\hline \multicolumn{1}{|c|}{ Element of the structure } & \multicolumn{2}{c|}{ Parameter value } \\
\cline { 2 - 3 } & Admissible & Soil cover thickness $30 \mathrm{~cm}$ \\
\hline Underground pipeline & Soil cover thickness $50 \mathrm{~cm}$ & $\begin{array}{c}\text { Soil surface subsidence behind the } \\
\text { protections: } 10 \mathrm{~cm}\end{array}$ \\
\hline Bank and bottom protections: inlet and outlet & $\begin{array}{c}\text { Soil surfe subsidence behind the } \\
\text { protections-more than } 20 \mathrm{~cm}\end{array}$ \\
\hline
\end{tabular}




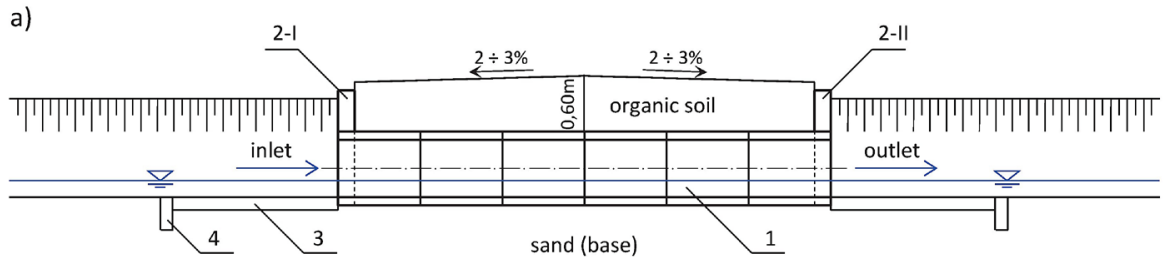

b)

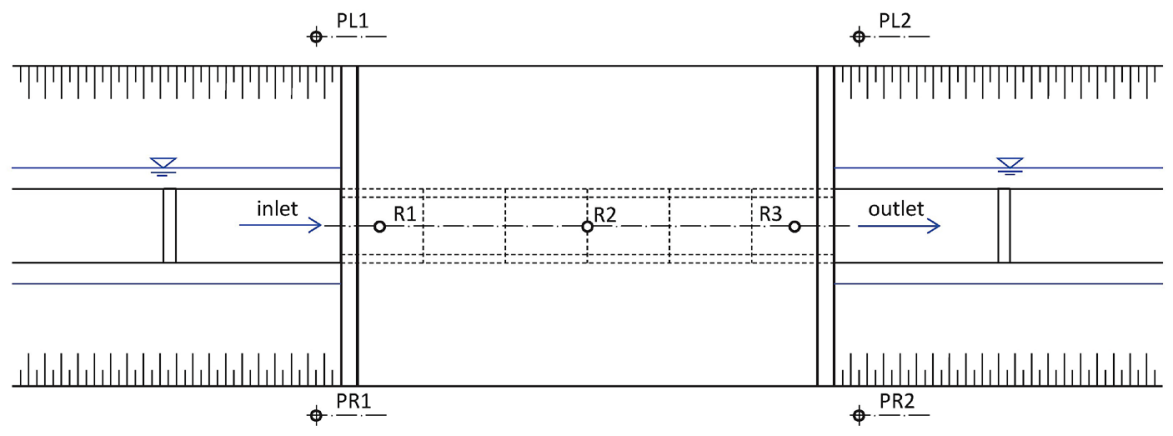

Fig. 3. Scheme of the culvert at the Solec research site: longitudinal cross-section (a) plane view (b): 1 - concrete pipeline $(d=0.60 \mathrm{~m}) ; 2$ - protections (inlet I and outlet II); 3 - concrete base; 4 - curb; R1,2,3 - measurement spots of the pipeline covering; PL1, PR1 - measurement points of inlet protections exposure; PL2, PR2 - measurement points of outlet protections exposure

excessive inclination and cracks of those culverts were noted.

Considering the status of culvert-gates, the elevations of the upper edge of their protections were found to be rather variable at the inlet and outlet part (Figure 6a and b). It is worth stressing that at the inlet part, which underwent water damming for subirrigation in the past, the protections were significantly overgrown by turf and a smaller number of damaged protections occurred ( 2 cases). At the outlet sections (lower water level), the overgrowing degree became definitely smaller, while the damage score was visibly higher (Figure 6b). Those differences may be explained by the fact that water damming at the inlet of culvert-gates resulted in a higher soil moisture content that contributed to a lower subsidence rate. At the same time, such conditions provided for the vegetation development in the neighborhood of the structures, likely to make

a)

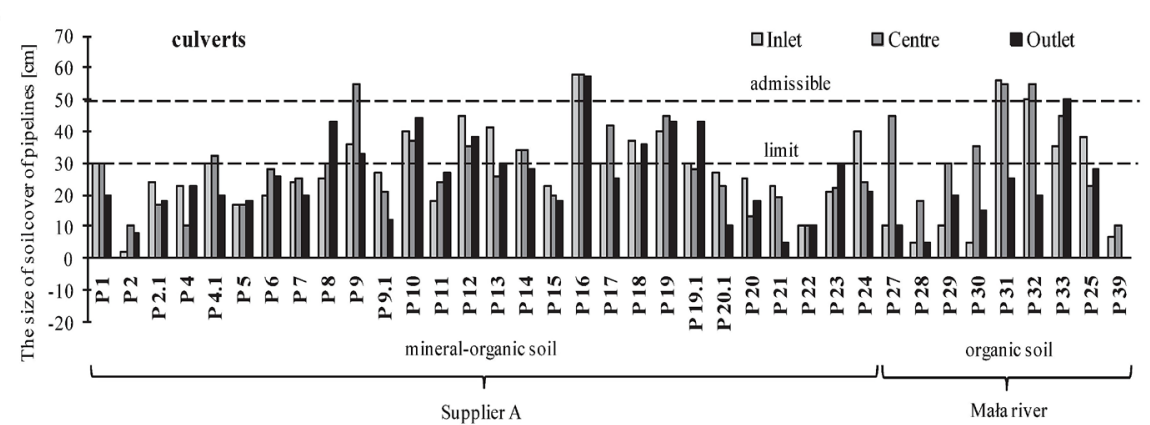

b)

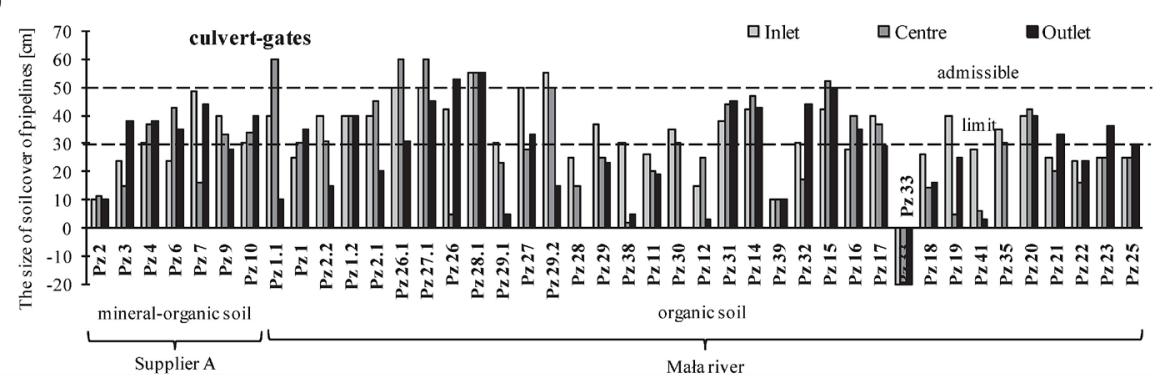

Fig. 4. a Covering thickness of the culverts' pipelines; $\mathbf{b}$ Covering thickness of the culvert-gates' pipelines 
a)

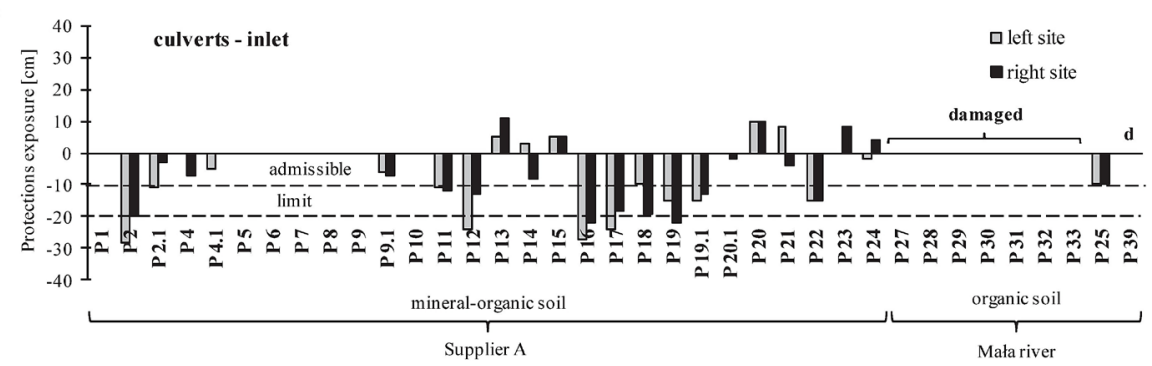

b)

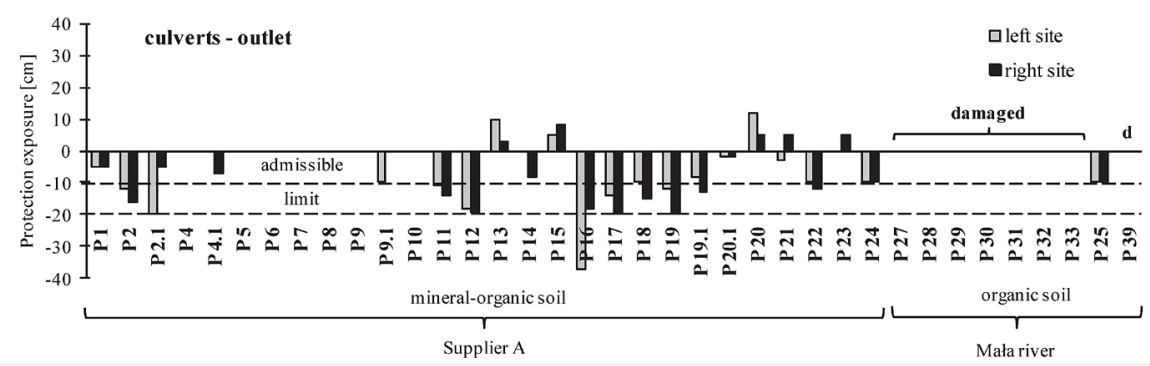

Fig. 5. a Culvert protections exposure at the inlet; b Culvert protections exposure at the outlet

the protections overgrown (Figure 6a). In the case of the protections of the outlet part (lower water) their significant exposure was revealed, as well as serious damage and no turf overgrowth (Figure 6b).

\section{Estimation of soil subsidence rate at the structures and in their vicinity}

Taking into consideration the original covering thickness of the analyzed pipelines in 1971, equal to $60 \mathrm{~cm}$ (the post-construction phase) and the measurements of that parameter in 2014, an average yearly rate of subsidence ( $\mathrm{cm} /$ year) was estimated for the inlet, middle and outlet part of the culverts (Table 2) and culvert-gates (Table 3 ). The available data proved a similar rate of that process on the whole length of underground culvert pipelines, amounting to $0.75-0.83 \mathrm{~cm} /$ year on average. In the case of culvert-gates, the averaged subsidence of the soil above their pipelines tends to be the smallest at the inlet, reaching $0.63 \mathrm{~cm} /$ year, slightly higher noted for the middle $(0.73 \mathrm{~cm} /$ year $)$ while the highest found at the outlet-about $0.80 \mathrm{~cm} /$ year (on average). Particular attention was paid to the pipeline of the structure pz33, the upper surface of which overtopped the surrounding terrain by $20 \mathrm{~cm}$ in 2014

a)

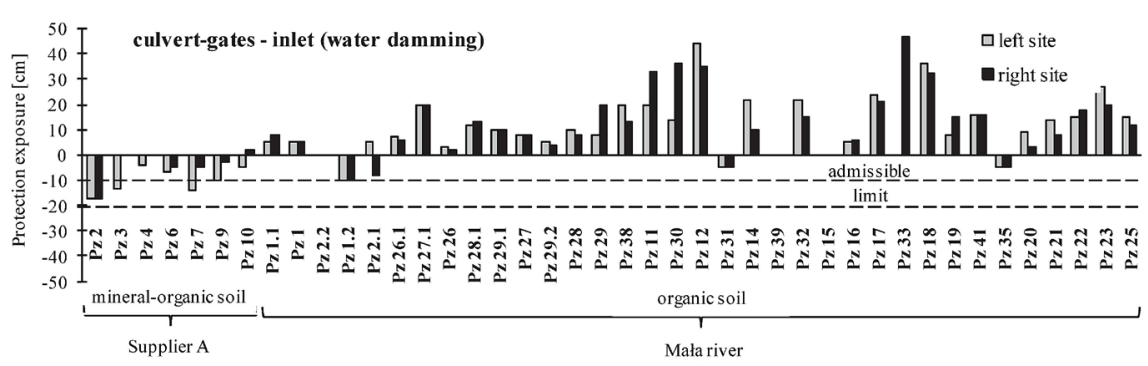

b)

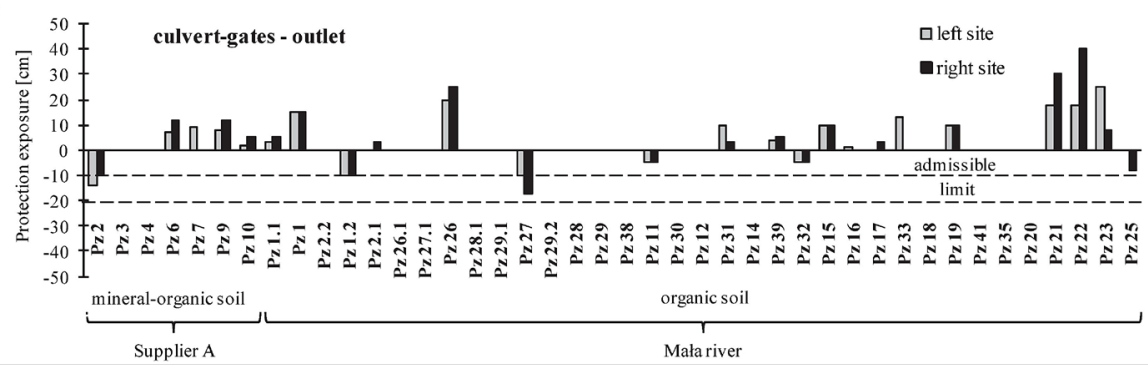

Fig. 6. a Culvert-gate protections exposure at the inlet; b Culvert-gate protections exposure at the outlet 
Table 2. Average subsidence rates [cm/year]-culverts

\begin{tabular}{|c|c|c|c|c|c|c|c|c|}
\hline \multirow{4}{*}{ No. } & \multirow{4}{*}{$\begin{array}{l}\text { Structure } \\
\text { code }\end{array}$} & \multicolumn{7}{|c|}{ Average yearly subsidence [cm/year] } \\
\hline & & \multicolumn{3}{|c|}{ over the pipeline } & \multicolumn{4}{|c|}{ behind protections } \\
\hline & & \multirow{2}{*}{ inlet } & \multirow{2}{*}{ middle } & \multirow{2}{*}{ outlet } & \multicolumn{2}{|c|}{ inlet } & \multicolumn{2}{|c|}{ outlet } \\
\hline & & & & & left & right & left & right \\
\hline 1 & p 1 & 0.70 & 0.70 & 0.93 & 0.00 & 0.00 & 0.12 & 0.12 \\
\hline 2 & $\mathrm{p} 2$ & 1.35 & 1.16 & 1.21 & 0.65 & 0.47 & 0.28 & 0.37 \\
\hline 3 & $\mathrm{p} 2.1$ & 0.84 & 1.00 & 0.98 & 0.26 & 0.07 & 0.47 & 0.12 \\
\hline 4 & $\mathrm{p} 4$ & 0.86 & 1.16 & 0.86 & 0.00 & 0.16 & 0.00 & 0.00 \\
\hline 5 & p 4.1 & 0.70 & 0.65 & 0.93 & 0.12 & 0.00 & 0.00 & 0.16 \\
\hline 6 & p 5 & 1.00 & 1.00 & 0.98 & 0.00 & 0.00 & 0.00 & 0.00 \\
\hline 7 & p 6 & 0.93 & 0.74 & 0.79 & 0.00 & 0.00 & 0.00 & 0.00 \\
\hline 8 & p 7 & 0.84 & 0.81 & 0.93 & 0.00 & 0.00 & 0.00 & 0.00 \\
\hline 9 & p 8 & 0.81 & 0.70 & 0.40 & 0.00 & 0.00 & 0.00 & 0.00 \\
\hline 10 & p 9 & 0.56 & 0.12 & 0.63 & 0.00 & 0.00 & 0.00 & 0.00 \\
\hline 11 & p 9.1 & 0.77 & 0.91 & 1.12 & 0.14 & 0.16 & 0.23 & 0.00 \\
\hline 12 & $\mathrm{p} 10$ & 0.47 & 0.53 & 0.37 & 0.00 & 0.00 & 0.00 & 0.00 \\
\hline 13 & $\mathrm{p} 11$ & 0.98 & 0.84 & 0.77 & 0.26 & 0.28 & 0.26 & 0.33 \\
\hline 14 & $\mathrm{p} 12$ & 0.35 & 0.58 & 0.51 & 0.56 & 0.30 & 0.42 & 0.44 \\
\hline 15 & $p 13$ & 0.44 & 0.79 & 0.70 & +0.12 & +0.26 & +0.23 & +0.07 \\
\hline 16 & p 14 & 0.60 & 0.60 & 0.74 & +0.07 & 0.19 & 0.00 & 0.19 \\
\hline 17 & $\mathrm{p} 15$ & 0.86 & 0.93 & 0.98 & +0.12 & +0.12 & +0.12 & +0.19 \\
\hline 18 & p 16 & 0.05 & 0.05 & 0.07 & 0.63 & 0.51 & 0.86 & 0.42 \\
\hline 19 & p 17 & 0.70 & 0.42 & 0.81 & 0.56 & 0.42 & 0.33 & 0.47 \\
\hline 20 & p 18 & 0.53 & 0.70 & 0.56 & 0.23 & 0.44 & 0.23 & 0.35 \\
\hline 21 & p 19 & 0.47 & 0.35 & 0.40 & 0.35 & 0.51 & 0.28 & 0.47 \\
\hline 22 & p 19.1 & 0.70 & 0.74 & 0.40 & 0.35 & 0.30 & 0.19 & 0.30 \\
\hline 23 & $\mathrm{p} 20.1$ & 0.77 & 0.86 & 1.16 & 0.00 & 0.05 & 0.05 & 0.05 \\
\hline 24 & p 20 & 0.81 & 1.09 & 0.98 & +0.23 & +0.23 & +0.28 & +0.12 \\
\hline 25 & p 21 & 0.86 & 0.95 & 1.28 & +0.19 & 0.09 & 0.07 & +0.12 \\
\hline 26 & p 22 & 1.16 & 1.16 & 1.16 & 0.35 & 0.35 & 0.23 & 0.28 \\
\hline 27 & p 23 & 0.91 & 0.88 & 0.70 & 0.00 & +0.19 & 0.00 & +0.12 \\
\hline 28 & p 24 & 0.47 & 0.84 & 0.91 & 0.05 & +0.09 & 0.23 & 0.23 \\
\hline 29 & p 27 & 1.16 & 0.35 & 1.16 & dam. & dam. & dam. & dam. \\
\hline 30 & p 28 & 1.28 & 0.98 & 1.28 & dam. & dam. & dam. & dam. \\
\hline 31 & p 29 & 1.16 & 0.70 & 0.93 & dam. & dam. & dam. & dam. \\
\hline 32 & p 30 & 1.28 & 0.58 & 1.05 & dam. & dam. & dam. & dam. \\
\hline 33 & p 31 & 0.09 & 0.12 & 0.81 & dam. & dam. & dam. & dam. \\
\hline 34 & p 32 & 0.23 & 0.12 & 0.93 & dam. & dam. & dam. & dam. \\
\hline 35 & p 33 & 0.58 & 0.35 & 0.23 & dam. & dam. & dam. & dam. \\
\hline 36 & p 25 & 0.51 & 0.86 & 0.74 & 0.23 & 0.23 & 0.23 & 0.23 \\
\hline 37 & p 39 & 1.23 & 1.16 & 1.40 & dam. & dam. & dam. & dam. \\
\hline
\end{tabular}

(Figure 4b) meaning that within the period of 43 years (1971-2014) the subsidence rate equaled about $80 \mathrm{~cm}$, and the yearly average rate at the whole length of that pipeline reached approximately $1.86 \mathrm{~cm} /$ year.

As summarized in Table 4, the protections of the culvert-gates were subject to overgrowing to a several times higher degree than in the case of the culverts (from 3 to about 5 times higher). On the other hand, the subsidence fractions noted for the culverts which did not serve to rise the water levels (no water damming at inlet) were found to be about 2 to 3 times higher than for culvertgates. Equal fractions of the damage at the inlet and outlet sections were evident for the culverts, while becoming considerably lower at the inlet of culvert-gates and again comparable for their outlet sections. Finally, similar observations seem to be valid for (0)-neutral cases. 
Table 3. Average subsidence rates [cm/year]-culvert-gates

\begin{tabular}{|c|c|c|c|c|c|c|c|c|}
\hline \multirow{4}{*}{ No. } & \multirow{4}{*}{$\begin{array}{l}\text { Structure } \\
\text { code }\end{array}$} & \multicolumn{7}{|c|}{ Average yearly subsidence [cm/year] } \\
\hline & & \multicolumn{3}{|c|}{ over the pipeline } & \multicolumn{4}{|c|}{ behind protections } \\
\hline & & \multirow{2}{*}{ inlet } & \multirow{2}{*}{ middle } & \multirow{2}{*}{ outlet } & \multicolumn{2}{|c|}{ inlet } & \multicolumn{2}{|c|}{ outlet } \\
\hline & & & & & left & right & left & right \\
\hline 1 & pz 2 & 1.16 & 1.14 & 1.16 & 0.40 & 0.40 & 0.33 & 0.23 \\
\hline 2 & pz 3 & 0.84 & 1.05 & 0.51 & 0.30 & 0.00 & 0.00 & 0.00 \\
\hline 3 & pz 4 & 0.70 & 0.53 & 0.51 & 0.09 & 0.00 & 0.00 & 0.00 \\
\hline 4 & pz 6 & 0.84 & 0.40 & 0.58 & 0.16 & 0.12 & +0.16 & +0.28 \\
\hline 5 & pz 7 & 0.26 & 1.02 & 0.37 & 0.33 & 0.12 & +0.21 & dam. \\
\hline 6 & $\mathrm{pz} 9$ & 0.47 & 0.63 & 0.74 & 0.23 & 0.07 & +0.19 & +0.28 \\
\hline 7 & pz 10 & 0.70 & 0.60 & 0.47 & 0.12 & +0.05 & +0.05 & +0.12 \\
\hline 8 & $\mathrm{pz} 1.1$ & 0.47 & 0.00 & 1.16 & +0.12 & +0.19 & +0.07 & +0.12 \\
\hline 9 & $\mathrm{pz} 1$ & 0.81 & 0.70 & 0.58 & +0.12 & +0.12 & +0.35 & +0.35 \\
\hline 10 & pz 2.2 & 0.47 & 0.67 & 1.05 & 0.00 & 0.00 & 0.00 & 0.00 \\
\hline 11 & $\mathrm{pz} 1.2$ & 0.47 & 0.47 & 0.47 & 0.23 & 0.23 & 0.23 & 0.23 \\
\hline 12 & pz 2.1 & 0.47 & 0.35 & 0.93 & +0.12 & 0.19 & 0.00 & +0.07 \\
\hline 13 & pz 26.1 & 0.23 & 0.00 & 0.67 & +0.16 & +0.14 & dam. & dam. \\
\hline 14 & pz 27.1 & 0.23 & 0.00 & 0.35 & +0.47 & +0.47 & dam. & dam. \\
\hline 15 & pz 26 & 0.42 & 1.28 & 0.16 & +0.07 & +0.05 & +0.47 & +0.58 \\
\hline 16 & pz 28.1 & 0.12 & 0.12 & 0.12 & +0.28 & +0.30 & dam. & dam. \\
\hline 17 & pz 29.1 & 0.70 & 0.86 & 1.28 & +0.23 & +0.23 & dam. & dam. \\
\hline 18 & pz 27 & 0.23 & 0.74 & 0.63 & +0.19 & +0.19 & 0.23 & 0.40 \\
\hline 19 & pz 29.2 & 0.12 & 0.23 & 1.05 & +0.12 & +0.09 & dam. & dam. \\
\hline 20 & pz 28 & 0.81 & 1.05 & 1.40 & +0.23 & +0.19 & dam. & dam. \\
\hline 21 & pz 29 & 0.53 & 0.81 & 0.86 & +0.19 & +0.47 & dam. & dam. \\
\hline 22 & pz 38 & 0.70 & 1.35 & 1.28 & +0.47 & +0.30 & dam. & dam. \\
\hline 23 & pz 11 & 0.79 & 0.93 & 0.95 & +0.47 & +0.77 & 0.12 & 0.12 \\
\hline 24 & pz 30 & 0.58 & 0.70 & 1.40 & +0.33 & +0.84 & 0.00 & 0.00 \\
\hline 25 & pz 12 & 1.05 & 0.81 & 1.33 & +1.02 & +0.81 & dam. & dam. \\
\hline 26 & pz 31 & 0.51 & 0.37 & 0.35 & 0.12 & 0.12 & +0.23 & +0.07 \\
\hline 27 & pz 14 & 0.42 & 0.30 & 0.40 & +0.51 & +0.23 & 0.00 & 0.00 \\
\hline 28 & pz 39 & 1.16 & 1.16 & 1.16 & dam. & dam. & +0.09 & +0.12 \\
\hline 29 & pz 32 & 0.70 & 1.00 & 0.37 & +0.51 & +0.35 & 0.12 & 0.12 \\
\hline 30 & pz 15 & 0.42 & 0.19 & 0.23 & 0.00 & 0.00 & +0.23 & +0.23 \\
\hline 31 & pz 16 & 0.74 & 0.47 & 0.58 & +0.12 & +0.14 & +0.02 & 0.00 \\
\hline 32 & pz 17 & 0.47 & 0.53 & 0.72 & +0.56 & +0.49 & 0.00 & +0.07 \\
\hline 33 & pz 33 & 1.86 & 1.86 & 1.86 & dam. & +1.09 & +0.30 & dam. \\
\hline 34 & pz 18 & 0.79 & 1.07 & 1.02 & +0.84 & +0.74 & 0.00 & 0.00 \\
\hline 35 & pz 19 & 0.47 & 1.28 & 0.81 & +0.19 & +0.35 & +0.23 & +0.23 \\
\hline 36 & pz 41 & 0.74 & 1.26 & 1.33 & +0.37 & +0.37 & dam. & dam. \\
\hline 37 & pz 35 & 0.58 & 0.70 & 1.40 & 0.12 & 0.12 & dam. & dam. \\
\hline 38 & pz 20 & 0.47 & 0.42 & 0.47 & +0.21 & +0.07 & dam. & dam. \\
\hline 39 & pz 21 & 0.81 & 0.93 & 0.63 & +0.33 & +0.19 & +0.42 & +0.70 \\
\hline 40 & pz 22 & 0.84 & 1.02 & 0.84 & +0.35 & +0.42 & +0.42 & +0.93 \\
\hline 41 & pz 23 & 0.81 & 0.81 & 0.56 & +0.63 & +0.47 & +0.58 & +0.19 \\
\hline 42 & pz 25 & 0.81 & 0.81 & 0.72 & +0.35 & +0.28 & 0.00 & 0.19 \\
\hline
\end{tabular}

\section{DISCUSSION}

The considered issue, being discussed in relevant literature, is the lack of proper exploitation and maintenance of drainage-irrigation infrastructure [Nyc et al. 2009]. Moreover, all the systems located on organic soils are constrained by the subsidence-related problems. Followed by the final disappearance of organic soils, the actual status and functioning of hydraulic structures is also affected, visible through banks and bottom subsidence, shallowing of the ditches, variations 
Table 4. Subsidence phenomena summary [\%]

\begin{tabular}{|l|c|c|c|c|c|c|c|c|}
\hline \multirow{3}{*}{ Phenomenon } & \multicolumn{4}{|c|}{ Culverts-behind protections [\%] } & \multicolumn{4}{c|}{ Culvert-gates-behind protections [\%] } \\
\cline { 2 - 12 } & \multicolumn{3}{|c|}{ Inlet } & \multicolumn{2}{c|}{ Outlet } & \multicolumn{2}{c|}{ Inlet } & \multicolumn{2}{c|}{ Outlet } \\
\cline { 2 - 11 } & left & right & left & right & left & right & left & right \\
\hline Overgrowing (+) & 13 & 13 & 8 & 13 & 67 & 69 & 38 & 36 \\
\hline Subsidence (-) & 38 & 43 & 43 & 43 & 25 & 19 & 12 & 14 \\
\hline Neutral (0) & 27 & 22 & 27 & 21 & 4 & 10 & 21 & 17 \\
\hline $\begin{array}{l}\text { Damaged } \\
\text { (dam.) }\end{array}$ & 22 & 22 & 22 & 22 & 4 & 2 & 28 & 33 \\
\hline
\end{tabular}

of their slope, exposure of underground pipelines of the culverts and culvert-gates [Jurczuk 2011; Querner et al. 2012; Oleszczuk et al. 2014; 2017].

The analyzed part of Solec subirrigation system (F5-drainage-irrigation experimental plot) was subject to long-term observations of organic soil surface subsidence that gave insight and constituted a basis for comparisons with the local subsidence in the vicinity of the structures. The period 1978-2015 revealed the range of 0.06 to $1.56 \mathrm{~cm} /$ year of the peatland surface subsidence while the average rate was equal to $0.68 \mathrm{~cm} /$ year [Gąsowska et al. 2019] which is fairly comparable to the values achieved for the structures. In order to create reference for comparisons, the case of drained organic soils devoted to meadowtype use exhibited similar surface subsidence rates $(0.5-2.5 \mathrm{~cm} /$ year) in Holland [Schipper et al. 2002], in the USA: $0.2-1.1 \mathrm{~cm} /$ year [Snowden 1980], in the North-Eastern Germany [Kluge et al. 2008] ranging from 0.2 to $1.6 \mathrm{~cm} /$ year and from 1 to $3 \mathrm{~cm} /$ year in the Eastern Ukraine [Lipka et al. 2017] while from 1 to $3 \mathrm{~cm} /$ year for the Polish conditions [Jurczuk 2000; Ilnicki et al. 2016]. The data above corresponds with the measured long term (1971-2014) subsidence rate of the drained organic soils in the vicinity of the structures (culverts and culvert-gates) located within the research area $(0.63-0.83 \mathrm{~cm} /$ year $)$.

Regardless of the congestion, machinery runs, organic matter mineralization, and the peat soil layer being disconnected from bedrock as well as groundwater table, the subsidence rate remained insignificant $(0.63-0.83 \mathrm{~cm} /$ year $)$ over the pipelines. However, in the long run the process itself becomes dangerous for the stability and the functioning of communication and water damming structures within the subirrigation system as considered herein. As a consequence, the covering of underground pipes of the culverts and culvertgates becomes smaller which may finally lead to their complete exposure. Then, the negative impact of the atmospheric conditions becomes evident, but also pipe displacements, unsealing and mechanical damage. In order to restore previous functions of the analyzed structures that is restricting the outflow and retaining water within a subirrigation system, the renovation seems indispensable with the aim to reintroduce at least limit values of the analyzed technical parameters (underground pipelines covering and refilling soil material in the closest surroundings of the protections). This would then become a basis for a wise water management to preserve the status of organic soils and any hydrologic alterations to better control subsidence-related phenomena.

\section{CONCLUSIONS}

The physical condition and functioning of hydraulic structures, especially on drained peatland areas, deserves particular attention. This was the reason to examine 37 culverts and 42 culvertgates existing within the research area, one case of each preserved the admissible value of pipelines covering at their whole length. Owing to the organic soil congestion and subsidence, the covering thickness of $38.5 \%$ of the culvert pipelines and $36 \%$ of culvert-gates did not exceed the limit value $(30 \mathrm{~cm})$ at the whole length $(1=6.0 \mathrm{~m})$ in the period of 43 years (1971-2014).

Soil surface lowering in the vicinity of the protections of communication structures (culverts) was found to be similar both at the inlet and outlet part. The range of that lowering may be attributable predominantly to the occurring organic soil type and thickness. In the second analyzed case, i.e. the culverts sitting on mineral-organic bed (along supplier A as it was previously mentioned), the noticeable changes in soil surface elevation were considered as insignificant. Furthermore, at all spots where organic soils thickness ranged from 1.0 to $1.2 \mathrm{~m}$, the exposure of the protections was higher than the limit value $(20 \mathrm{~cm})$ for which 8 cases of notable damage were found. 
The case of protections at the inlet to culvertgates showed little subsidence and overgrowing with turf, which can be attributable to water damming for irrigation (upper water sections). In this manner, a higher soil moisture content was maintained in the vicinity of the structures that contributed to a lower subsidence rate, but also turf and vegetation expansion.

On the other hand, it was found that the protections at the outlet part of culvert-gates underwent considerable damage (12 cases reported). The underlying mechanisms involved lower water levels in ditches (lower water at the outlet section) favorable for more advanced subsidence of organic soils.

Average long-term (1971-2014) subsidence rate of organic soils over the analyzed pipelines ranged from $0.63 \mathrm{~cm} /$ year to $0.83 \mathrm{~cm} /$ year. The achieved values showed similarity to the average subsidence rates of the organic soil surface within the study site, as well as to other case studies as given in the available literature data.

\section{REFERENCES}

1. Bednarczyk S., Bolt A., Mackiewicz S. 2009. Stability and safety of weirs and dams. Gdansk Technical University Press, Gdańsk (in Polish).

2. Berglund Ö., Berglund K. 2010. Distribution and cultivation intensity of agricultural peat and gyttja soils in Sweden and estimation of greenhouse gas emissions from cultivated peat soils. Geoderma, 154, 173-180.

3. Chrzanowski S., Szuniewicz J. 2002. The disappearance of organic soils in intensive drainage peatland near Biebrza. Water - Environment - Rural Areas, 2(2), 129-137 (in Polish).

4. Couwenberg J. 2011. Greenhouse gas emissions from managed peat soils: is the IPCC reporting guidance realistic? Mires and Peat, 8(02), 1-10.

5. Czaplak I., Dembek W. 2000. Torfowiska Polski jako źródło emisji dwutlenku węgla.[ Polish peatlands as a source of carbon dioxide emission]. Educational Annals, 6/200, 61-71. Institute of Land Reclamation and Grassland Farming Press, Falenty, Poland (in Polish).

6. Deverel S., Ingrum T., Leighton D. 2016. Present - day oxidative subsidence of organic soils and mitigation in the Sacramento - San Joaquin Delta, California, USA. Hydrogeology Journal, 24, 569-586.

7. Gąsowska M., Oleszczuk R., Urbański J. 2019. The estimation of the subsidence rate of drained peatland and verification of empirical equations of this process. Scientific Review - Engineering and Environmental Sciences, 28 (1), 95-104.

8. Gebhard S., Fleige H., Horn R. 2012. Anisotropic shrinkage of mineral and organic soils and its impact on soil hydraulic properties. Soil Tillage Research, 125, 96-104.

9. Grand- Clement E., Anderson K., Smith D., Luscombe D., Gatis N., Ross M., Brazier E. 2013. Evaluating ecosystem goods and services after restoration of marginal upland peatlands in South - West England. Journal of Applied Ecology, 50, 324-334.

10. Grzywna A. 2017. The degree of peatland subsidence resulting from drainage of land. Environmental Earth Sciences, 76(559), 1-8.

11. Hendriks R. 2004. An analytical equation for describing the shrinkage characteristics of peat soils. Proc. of the 12th International Peat Congress, 1343-1348.

12. Hoogland T., van den Akker J., Brus D. 2012. Modelling the subsidence of peat soils in the Dutch coastal area. Geoderma, 171-172, 92-97.

13. Ilnicki P., Szajdak L. 2016. Peatland disappearance. Wydawnictwo PTPN, Poznań (in Polish).

14. Joosten H., Clarke D. 2002. Wise use of mires and peatlands - background and principles including a framework for decision - making. International Mire Conservation Group and International Peat Society. Saarijärvi, Finland.

15. Jurczuk S. 2000. The Influence of Water Regulations on Subsidence and Mineralisation of Organic Soils. Biblioteczka Wiadomości IMUZ 96, Falenty (in Polish).

16. Jurczuk S. 2011. Melioracyjne uwarunkowania zachowania materii organicznej w użytkowanych łąkowo glebach pobagiennych. Water-Environment-Rural Areas. Treatises and Monographs no 30, Falenty, Institute of Land Reclamation and Grassland Farming press (in Polish).

17. Kaca E., Interewicz A. 1991. Metoda oceny stanu technicznego urządzeń melioracyjnych w systemach nawodnień podsiąkowych [Estimation of subirrigation hydraulic strucutres physical status]. Postęp w projektowaniu i eksploatacji systemów nawodnień podsiąkowych. Konferencja naukowa Brok. Wydawnictwo SGGW (WULS Publishing) (in Polish).

18. Kluge B., Wessolek G., Facklam M., Lorenz M., Schwarzel K. 2008. Longterm carbon loss and $\mathrm{CO} 2-\mathrm{C}$ release of drained peatland soils in northeast Germany. European Journal of Soil Science, 59, 1076-1086.

19. Lipka K., Zając E., Hlotov V., Siejka Z. 2017. Disappearance rate of a peatland in Dublany near Lviv (Ukraine) drained in 19th century. Mires and Peat, $19,1-15$. 
20. Mioduszewski W., Dembek W. 2009. Woda na obszarach wiejskich [Water in Rural Areas]. Wyd. IMUZ, Falenty [Institute of Land Reclamation and Grassland Farming Press].

21. Nyc K., Pokładek R. 2009. Eksploatacja systemów melioracyjnych podstawą racjonalnej gospodarki wodnej w środowisku przyrodniczo-rolniczym. Współczesne problemy inżynierii środowiska XIV. Wyd. UWP [Wroclaw University of Life Sciences Publishing] (in Polish).

22. Oleszczuk R., Regina K., Szajdak L., Höper H., Maryganowa V. 2008. Impacts of agricultural utilization of peat soils on the greenhouse gas balance. Peatlands and Climate Change. International Peat Society. Jyväskylä, Finland.

23. Oleszczuk R .2011. Analysis of volume changes characteristics of drying and rewetting fen peat soils. Warsaw University of Life Sciences - SGGW Press, Warsaw (in Polish).

24. Oleszczuk R., Urbański J., Gąsowska M. 2014. The influence of morphological changes of small lowland river on discharge rate. Annals of Warsaw University of Life Sciences - SGGW Land Reclamation, 46(4), 17-28.

25. Oleszczuk R., Gąsowska M., Guz G., Urbański J., Hewelke E. 2017. The influence of subsidence and disappearance of organic moorsh soils on longitudinal sub - irrigation ditch profiles. Acta Scientarum Polonorum Formatio Circumiectus, 16(3), 3-13 (in Polish).
26. Oleszczuk R., Stocka I., Urbański J., Hewelke E. 2017. Stan techniczny budowli piętrzących na przykładzie wybranego systemu nawodnień podsiąkowych. Woda - Środowisko - Obszary Wiejskie, 17 (57), 89 - 100 (in Polish).

27. Querner E., Jansen P., van den Akker J., Kwakernaak C. 2012. Analysing water level strategies to reduce soil subsidence in Dutch peat meadows. Journal of Hydrology, 446-447, 59-69.

28. Schipper L., McLeod M. 2002. Subsidence rates and carbon loss in peat soils following conversion to pasture in the Waikato region, New Zealand. Soil Use and Management, 18, 91-93.

29. Snowden J. 1980. Drainage-induced land subsidence in metropolitan New Orleans. Louisiana, U.S.A. University of New Orleans.

30. Urbański J., Oleszczuk R., Brandyk A., Zając E. 2018. Estimation of lowland river cross-section changes for different soils. Annals of Warsaw University of Life Sciences - SGGW Land Reclamation, 50(4), 291-300.

31. Wallage Z., Holden J., McDonald T. 2006. Drain blocking: an effective treatment for reducing dissolved organic carbon loss and water discolouration in a drained peatland. Science of the Total Environment, 367, 811-821.

32. Zając E., Zarzycki J., Ryczek M. 2018. Substrate quality and spontaneous revegetation of extracted peatland: case study of an abandoned Polish mountain bog. Mires and Peat, 21, 1-14. 